\title{
PENGARUH KESADARAN MEMBAYAR PAJAK, PERSEPSI ATAS EFEKTIVITAS SISTEM PERPAJAKAN, DAN PEMAHAMAN PERATURAN PEMERINTAH NOMOR 23 TAHUN 2018 TERHADAP KEMAUAN MEMBAYAR PAJAK (PADA UMKM SEKTOR PERDAGANGAN DI KABUPATEN KLATEN)
}

\author{
Dhea Mayang Pangesti \\ Program Studi Akuntansi Fakultas Ekonomi Universitas Negeri Yogyakarta \\ dheamayang01@gmail.com \\ Amanita Novi Yushita \\ Program Studi Akuntansi Universitas Negeri Yogyakarta \\ amanitanovi@uny.ac.id
}

\begin{abstract}
Abstrak: Pengaruh Kesadaran Membayar Pajak, Persepsi Atas Efektivitas Sistem Perpajakan dan Pemahaman Peraturan Pemerintah Nomor 23 Tahun 2018 terhadap Kemauan Membayar Pajak (Pada UMKM Sektor Perdagangan di Kabupaten Klaten). Penelitian ini bertujuan untuk mengetahui pengaruh Kesadaran Membayar Pajak, Persepsi atas Efektivitas Sistem Perpajakan dan Pemahaman Peraturan Pemerintah No. 23 Tahun 2018 terhadap Kemauan Membayar Pajak. Penelitian ini menggunakan metode kuantitatif. Populasi dalam penelitian ini adalah pelaku Usaha Mikro, Kecil, Menengah (UMKM) Kabupaten Klaten. Teknik pengambilan sampel dengan purposive sampling didapatkan sampel sebanyak 388 pelaku UMKM sektor perdagangan. Teknik pengumpulan data menggunakan kuesioner yang telah diuji validitas dan reliabilitasnya. Teknik analisis data menggunakan regresi linear sederhana dan berganda. Hasil penelitian ini menunjukkan bahwa Kesadaran Membayar Pajak, Persepsi atas Efektivitas Sistem Perpajakan, dan Pemahaman Peraturan Pemerintah No. 23 Tahun 2018 berpengaruh positif dan signifikan terhadap Kemauan Membayar Pajak, dibuktikan dengan nilai signifikansi 0,$000 ; 0,000$; dan 0,000 .
\end{abstract}

Kata kunci: Kesadaran Membayar Pajak, Persepsi Atas Efektivitas Sistem Perpajakan, Pemahaman PP No. 23 Tahun 2018, dan Kemauan Membayar Pajak

Abstract: The Effect of Tax Paying Awareness, Perception on the Effectiveness of the Taxation System and the Understanding of Government Regulation Number 23 Of 2018 on the Willingness to Pay Taxes (At SMEs' Trade Sector In Klaten). This study aims to determine the effect of Tax Paying Awareness, Perception of the Effectiveness of the Taxation System and Understanding of Government Regulation Number 23 of 2018 against the Will to Pay Taxes. This research used quantitative methods. The population in this study was Klaten District Micro, Small, Medium Enterprises (SMEs') businessmen. The sampling technique is purposive sampling which obtained a sample of 388 SMEs Trading Sector players. Data collection techniques is questionnaires that had been tested for the validity and reliability. The data analysis technique used in the research includes simple linier regression and multiple linear regression. The results of this study indicate that Tax Paying Awareness, Perception of the Effectiveness of the Tax System, and Understanding of Government Regulation No. 23 of 2018 have positive and significant effect on the willingness to pay taxes, as evidenced by significance 0,000; 0,000; and 0,000.

Keywords: Tax Paying Awareness, Perception of the Effectiveness of the Tax System, Understanding Government Regulation Nunmber 23 of 2018, and Willing to Pay Taxes 


\section{PENDAHULUAN}

Penerimaan negara salah satunya adalah pajak yang merupakan pendapatan sangat penting bagi pelaksanaan dan peningkatan pembangunan nasional. Pembangunan nasional sebagai salah satu cara untuk meningkatkan kesejahteraan masyarakat. Dalam UU Nomor 16 tahun 2009 tentang Ketentuan Umum dan Tata Cara Perpajakan, bahwa "Pajak adalah kontribusi wajib kepada negara yang terutang oleh orang pribadi atau badan yang bersifat memaksa berdasarkan UndangUndang, dengan tidak mendapatkan imbalan secara langsung dan digunakan untuk keperluan negara bagi sebesarbesarnya kemakmuran rakyat". Jadi, pajak merupakan iuran wajib yang dibayarkan baik orang pribadi maupun badan berdasarkan peraturan dan tidak mendapat balas jasa secara langsung.

Dalam pembayaran pajak di Indonesia ada dua sistem perpajakan dari Official Assesment System menjadi Self Assesment System. Self Assesment System yaitu sistem yang memberi Wajib Pajak wewenang untuk menghitung atau menetapkan sendiri jumlah pajak yang dibayarkan (Resmi, 2011:11). Sistem pembayaran pajak tersebut berlaku bagi semua objek pajak termasuk UMKM (Usaha Mikro, Kecil dan Menengah). Salah satu objek pajak yang potensial adalah Usaha Mikro, Kecil, dan Menengah yang atau UMKM.

Usaha Mikro, Kecil dan Menengah (UMKM) merupakan salah satu bagian terpenting dalam perekonomian kerakyatan di suatu wilayah maupun suatu Negara. Usaha Mikro, Kecil dan Menengah (UMKM) dipandang sebagai suatu penyelamat dalam proses perekonomian Indonesia yang mendorong laju pertumbuhan ekonomi dan mampu menyerap tenaga kerja karena UMKM sangat berperan penting dalam perekonomian Indonesia. Jumlah UMKM berkembang pesat dan terus bertambah setiap tahunnya. Menurut Data Badan Perencanaan Pembangunan Nasional, Badan Pusat Statistik, dan United Nation Population Fund memprediksi jumlah pelaku usaha mikro, kecil, dan menengah (UMKM) di Indonesia pada 2018 sebanyak 58,97 juta orang. Sedangkan jumlah penduduk Indonesia pada tahun 2018 diprediksi mencapai 265 juta jiwa. Pada tahun 2018 serta beberapa tahun ke depan diperkirakan jumlah pelaku UMKM akan terus bertambah.

Kontribusi sektor Usaha Mikro, Kecil dan Menengah (UMKM) terhadap produk domestik bruto (PDB) semakin meningkat dalam lima tahun terakhir. Kementerian Koperasi dan Usaha Kecil Menengah mencatat kontribusi sektor UMKM meningkat dari 57,84 persen menjadi 60,34 


\section{JURNAL NOMINAL / VOLUME VIII NOMOR 2 / TAHUN 2019}

persen dalam lima tahun terakhir dan serapan tenaga kerja pada sektor ini juga meningkat, dari 96,99 persen menjadi 97,22 persen pada periode yang sama (Kompas 2018:1 dalam www.kemenperin.go.id). Sektor UMKM sangat penting sebagai pilar utama pembentukan PDB. Kehadiran menjadi tonggak dalam menghadapi gejolak ekonomi tersebut.

Pajak yang dibayarkan oleh sektor UMKM menjadi sumber penerimaan negara yang sangat potensial, dan akan berpotensi besar pula dalam jumlah penerimaan pajak dari sektor tersebut. Meski UMKM berperan dominan terhadap perekonomian nasional, apabila dikaitkan dengan pemenuhan kewajiban perpajakan, terlihat bahwa kemauan membayar pajak pada UMKM masih rendah. Dilihat pada kontribusi penerimaan pajak menurut Menteri Keuangan Sri Mulyani Indrawati pada 2018 dari sektor UMKM berada dikisaran Rp5,7 triliun atau masih sangat minim apabila dibandingkan dengan total penerimaan perpajakan nasional yang mencapai sebesar Rp1.500 triliun (Sukarno, 2019:1 dalam www.ekonomi.bisnis.com).

Menurut Nugroho, Edwin (2016:3), "Penyebab kurangnya kemauan membayar pajak antara lain adalah asas perpajakan, yaitu bahwa hasil pemungutan pajak tersebut tidak langsung dinikmati oleh para wajib pajak". Banyak masyarakat tidak pernah tahu wujud nyata dari imbalan
Usaha Mikro Kecil dan Menengah (UMKM) dapat menjadi mesin penggerak perekonomian dan UMKM bisa menjadi penolong saat sebuah negara menghadapi krisis ekonomi. Keberadaan UMKM yang kuat merupakan modal utama pembangunan ekonomi serta pemungutan, oleh karena itu masyarakat menjadi enggan untuk membayarkan kewajibannya.

Di daerah Klaten terdapat banyak sekali UMKM namun tidak semua UMKM tersebut mempunyai NPWP guna memenuhi kewajibannya. Menurut Kepala Dinas Perdagangan, Perindustrian dan Koperasi Kabupaten Klaten jumlah UMKM di Klaten sebesar 53.000 yang memiliki NPWP hanya sekitar $65 \%$ tetapi belum semua mau melaksanakan kewajibannya dengan baik. Dari 65\% yang memiliki NPWP yang mau membayarkan kewajibannya hanya sekitar $30 \%$ atau sekitar 10.335 UMKM dan yang belum mau membayarkan pajaknya sekitar 24.115. Masih terdapat 35\% yang belum mempunyai NPWP. Tingkat kemauan membayar pajak rendah disebabkan karena kurangnya kesadaran akan pentingnya membayar pajak mereka merasa keberatan untuk membayar pajak karena dengan membayar pajak otomatis akan mengurangi penghasilan mereka, dan menurut pelaku usaha mereka banyak yang belum paham tentang penggunaan sistem perpajakan 


\section{JURNAL NOMINAL / VOLUME VIII NOMOR 2 / TAHUN 2019}

yang berbasis online jadi mereka harus mengantri ke kantor pajak untuk melaporkan kewajibannya, padahal apabila pelaku UMKM dapat memaksimalkan penggunaan sistem perpajakan saat ini maka mereka akan dengan mudah untuk melaporkan dan membayarkan pajaknya.

\section{KAJIAN LITERATUR}

Salah satu faktor yang mempengaruhi kemauan membayar pajak adalah kesadaran membayar pajak. Kunci kesadaran yang mendorong untuk mau membayarkan kewajibannya antara lain; paham tentang manfaat pajak yang dibayarkan, membayar pajak merupakan bentuk partisipasi dalam membangun negara dan harapan bahwa dengan membayar pajak akan berimbas pada kemajuan usaha. Menurut Mahfud, Muhammad dan Syukriy (2017:2) "Semakin tinggi kesadaran yang dimiliki wajib pajak maka semakin meningkatkan kemauan membayar kewajiban". Kesadaran waijb pajak dari sektor Usaha Mikro Kecil dan Menengah (UMKM) di Klaten, melaporkan pajak rendah. Banyak UMKM tersebut semata-mata NPWP hanya untuk sebagai syarat pengajuan kredit modal dan syarat pembuatan izin usaha saja.

Faktor yang tak kalah penting yakni persepsi atas efektivitas sistem perpajakan. lndonesia menerapkan self assessment system Wajib Pajak diberikan kepercayaan untuk menghitung memperhitungkan, menyetor, dan melaporkan kewajiban pajaknya sendiri. Sebelum adanya sistem yang mempermudah Wajib Pajak harus melaporkan dan membayar kewajiban pajaknya secara manual dan harus mengantri langsung ke kantor pajak. Untuk mempermudah Wajib Pajak dalam membayar dan melaporkan kewajiban pajaknya sistem pendukung dari DJP yaitu adanya e-filling, e-SPT, e-NPWP dan ebanking (Nugroho, Edwin, 2016:3).

Wajib Pajak mempunyai persepsi atau manfaat sendiri tentang sistem-sistem perpajakan. Dengan adanya e-filling, eSPT, e-NPWP, dan e-banking, persepsi Wajib Pajak atas sistem perpajakan meningkat karena semua sistem tersebut membuat Wajib Pajak dapat melakukan semua proses pajak. Tetapi beberapa masih terdapat Wajib Pajak yang mengalami kesulitan dalam mengakses sistem perpajakan yang berbasis online, dikarenakan wajib pajak belum paham dalam penggunaan internet dan merasa rumit untuk mengakses sistem berbasis online tersebut.

Tidak semua Wajib Pajak merasakan manfaat atas sistem perpajakan yang berbasis online melalui internet. Manfaat wajib pajak atas sistem tersebut berbedabeda. Ada wajib pajak yang memiliki manfaat lebih efektif dan memudahkan 
dalam penggunaan, namun ada juga wajib pajak yang kesulitan dengan sistem berbasis internet karena belum paham dalam penggunaannya. Hal tersebut yang dinamakan dengan persepsi. Peneliti melakukan observasi pra survey terhadap pelaku UMKM sektor perdagangan yang ditemui di beberapa Kecamatan yang ada di Kabupaten Klaten, persepsi mereka berbeda-beda. Tergantung dari pemilik usahanya, apabila pemilik usaha termasuk pada golongan muda mereka merasakan manfaat dari sistem DJP yang mempermudahkan mereka dalam membayarkan pajaknya tetapi apabila pemilik usaha tergolong tua maka mereka tidak tahu tentang tata cara dan penggunaan sistem DJP yang berbasis internet karena menurutnya mereka belum paham menggunakan internet dan terlalu rumit.

Faktor lain yang mempengaruhi yaitu pemahaman tentang peraturan pemerintah Nomor 23 Tahun 2018. Menurut Hardiningsih, Pancawati dan Nila (2011:5) "Pemahaman wajib pajak terhadap peraturan perpajakan adalah cara wajib pajak dalam memahami peraturan perpajakan yang telah ada”. Pemerintah juga secara resmi telah menerbitkan Peraturan Pemerintah Nomor 23 Tahun 2018 tentang Pajak Penghasilan atas penghasilan dari usaha yang diterima atau diperoleh Wajib Pajak yang memiliki peredaran bruto tertentu. Sebagian para pelaku UMKM di kabupaten Klaten belum mengetahui tentang peraturan pemerintah yang baru tersebut yang pengenaan tarif pajak sebesar $0,5 \%$ dari omzet. Penurunan tarif pajak dari $1 \%$ persen menjadi $0,5 \%$ diyakini menurunkan beban pajak sehingga bisa meningkatkan kemauan membayar pajak

UMKM di Kabupaten Klaten sektor Perdagangan adalah sektor yang paling banyak tersebar wilayah Kabupaten Klaten yaitu sebanyak 13.315. Hal tersebut memungkinkan bahwa UMKM sektor perdagangan menjadi salah satu sektor yang tingkat kemauan membayar pajaknya rendah. Sektor Usaha Mikro, Kecil dan Menegah dapat menjadi potensi yang bagus untuk menghimpun penerimaan pajak yang lebih besar di Klaten. Meski demikian, masih banyak UMKM di Kabupaten Klaten yang belum membayar pajak sesuai dengan ketentuan.

Sikap kemauan membayar pajak harus dimiliki oleh setiap wajib pajak agar penerimaan negara yang berasal dari pajak dapat maksimal. Untuk mengetahui apakah adanya kemungkinan pengusaha sudah melakukan kewajiban perpajakannya, peneliti ingin mengetahui Kesadaran Membayar Pajak; Persepsi atas Efektivitas Sistem Perpajakan; Pemahaman Peraturan Pemerintah Nomor 23 Tahun 2018 mempengaruhi Kemauan Membayar Pajak 


\section{JURNAL NOMINAL / VOLUME VIII NOMOR 2 / TAHUN 2019}

pada UMKM Sektor Perdagangan di Kabupaten Klaten.

Kesadaran menurut KBBI adalah hal yang dirasakan atau dialami oleh seseorang, keadaan mengerti dan merasa. Sadar artinya merasa, tahu atau ingat kepada keadaan yang sebenarnya. Kesadaran membayar pajak adalah keadaan dimana seseorang mengetahui atau memahami tentang tata cara membayar pajak. Masyarakat yang memiliki kesadaran dalam perpajakan berarti mau membayar pajak karena tidak dirugikan dari pemungutan pajak yang dilakukan dan merasa adanya paksaan.

Dalam kewajiban perpajakannya, kesadaran membayar pajak merupakan hal penting dalam penarikan pajak. Sadar artinya merasa, tahu atau ingat kepada keadaan yang sebenarnya. Individu yang memiliki kesadaran tinggi maka akan mengetahui dan mentaati ketentuan perpajakan yang berlaku serta memiliki kemauan untuk memenuhi kewajiban pajaknya. Selain itu, adanya kesadaran membayar pajak akan menumbuhkan motivasi dalam melaksanakan kewajiban perpajakannya, sehingga kemauan membayar pajaknya juga akan tinggi. Dengan demikian kesadaran membayar pajak akan berpengaruh positif terhadap kemauan membayar pajak pada UMKM sektor perdagangan di Kabupaten Klaten.
H1:Kesadaran Membayar Pajak berpengaruh Positif terhadap Kemauan Membayar Pajak pada UMKM Sektor Perdagangan di Kabupaten Klaten.

Indikator yang digunakan untuk mengukur variabel kesadaran membayar pajak diadopsi dan dimodifikasi dari Widayanti dan Nurlis (2010:8) yaitu; pajak merupakan bentuk patisipasi dalam menunjang pembangunan negara dan membiayai pengeluaran-pengeluaran negara, penundaan pembayaran pajak dan pengurangan beban pajak sangat merugikan negara, pajak ditetapkan dengan undangundang dan dapat dipaksakan, membayar pajak tidak sesuai dengan seharusnya dibayarkan akan merugikan negara, dan penyampaian SPT.

Persepsi menurut KBBI adalah tanggapan (penerimaan) langsung dari sesuatu, proses seseorang mengetahui beberapa hal melalui pancaindranya. Sedangkan efektivitas memiliki pengertian suatu pengukuran yang menyatakan seberapa jauh target (kualitas, kuantitas dan waktu) yang telah tercapai (Huda, Ainil 2015:4). Jadi, persepsi atas efektivitas sistem perpajakan merupakan kesan atau manfaat yang dirasakan oleh wajib pajak terhadap sistem pembayaran pajak.

Efektivitas sistem perpajakan dapat dirasakan oleh wajib pajak antara lain adanya sistem berbasis online yang dapat dilakukan di berbagai tempat, tidak harus 
datang ke Kantor Pajak, peraturan perpajakan juga dapat diakses secara cepat menggunakan internet. Semakin baik fasilitas yang disediakan oleh DJP akan meningkatkan kemauan wajib pajak dalam membayar pajak. Apabila Wajib Pajak dapat memaksimalkan sistem perpajakan dengan basis internet, akan dapat mudah dalam membayarkan pajaknya. Dengan demikian persepsi atas efektivitas sistem perpajakan akan berpengaruh positif terhadap kemauan membayar pajak pada UMKM sektor perdagangan di Kabupaten Klaten.

\section{H2: Persepsi Atas Efektivitas Sistem Perpajakan berpengaruh Positif terhadap Kemauan Membayar Pajak pada UMKM Sektor Perdagangan di Kabupaten Klaten.}

Indikator yang digunakan untuk mengukur variabel persepsi atas efektivitas sistem perpjakan diadopsi dan dimodifikasi Peraturan yang mudah untuk dipahami dan mudah diterapkan, seharusnya menjadikan Wajib Pajak mampu dan cenderung taat dalam menjalankan kewajiban perpajakannya. Dengan demikian pemahaman peraturan pemerintah no. 23 tahun 2018 akan berpengaruh positif terhadap kemauan membayar pajak pada UMKM sektor perdagangan di Kabupaten Klaten.

H3: Pemahaman Peraturan Pemerintah Nomor 23 Tahun 2018 berpengaruh dari Ayu, Ida dan Gayatri (2017:14) yaitu; jumlah pajak yang dibayar, pemanfaatan pajak, penyampaian SPT melalui online, peraturan perpajakan yang up to date, fasilitas perpajakan yang modern.

Menurut Hardiningsih, Pancawati dan Nila (2011:5) "Pemahaman Peraturan pemerintah adalah cara wajib pajak dalam memahami peraturan perpajakan yang telah ada". Masyarakat yang mengerti dan memahami sebuah peraturan maka akan melaksanakan peraturan tersebut selama tidak bersifat merugikan. Peraturan Pemerintah Nomor 23 Tahun 2018 bertujuan untuk mempermudah pemahaman dalam pemenuhan kewajiban perpajakan. Pelaksanaan disini berarti dengan diterapkannya tarif $0,5 \%$ dari omzet atau peredaran usaha merupakan wujud ketetapan yang bersifat meringankan dalam membayarkan kewajibannya karena tarif pajak tersebut turun dari $1 \%$ menjadi $0,5 \%$.

Positif terhadap Kemauan Membayar Pajak pada UMKM Sektor Perdagangan di Kabupaten Klaten.

Indikator yang digunakan untuk mengukur variabel persepsi atas efektivitas sistem perpjakan diadopsi dan dimodifikasi dari Fatmawati (2015:21) yaitu; Pengetahuan Wajib Pajak terkait ketentuan umum PP No. 23 Tahun 2018 dan

Indikator yang digunakan untuk mengukur variabel persepsi atas efektivitas sistem perpjakan diadopsi dan dimodifikasi 


\section{JURNAL NOMINAL / VOLUME VIII NOMOR 2 / TAHUN 2019}

dari Fatmawati (2015:21) yaitu;

Pengetahuan Wajib Pajak terkait ketentuan umum PP No. 23 Tahun 2018 dan

Pemahaman Wajib Pajak secara teknis berkaitan dengan PP No. 23 Tahun 2018.

Kesadaran yang tinggi itu sendiri muncul tidak lain berasal dari adanya motivasi wajib pajak. Apabila kesadaran wajib pajak tinggi yang datang dari motivasi untuk membayar pajak, maka kemauan untuk membayar pajakpun akan tinggi dan pendapatan negara dari pajak akan meningkat.

Persepsi atas efektivitas sistem perpajakan merupakan kesan atau manfaat yang dirasakan terhadap sistem perpajakan. DJP sudah memberikan fasilitas sistem untuk menunjang dalam pemenuhan wajib

pajak seperti sistem yang berbasis internet E-Filling, E-SPT, E-NPWP yang memudahkan agar lebih cepat untuk membayarkan atau melaporkan pajaknya. Sehingga dengan berbagai tawaran fasilitas yang mempermudah wajib pajak dalam membayar pajak akan menimbulkan persepsi yang baik dan kemauan untuk membayar pajaknya pun akan meningkat.

Menurut Hardiningsih, Pancawati dan Nila (2011) "pemahaman wajib pajak terhadap peraturan perpajakan adalah cara wajib pajak dalam memahami peraturan perpajakan yang telah ada". Seseorang yang memahami peraturan dengan baik, diwujudkan dengan tindakan yang selaras dengan peraturan. Wajib Pajak memahami dengan baik Peraturan Pemerintah Nomor 23 Tahun 2018 dengan baik, pemahaman tersebut akan tercermin dari apa yang Wajib Pajak tesebut lakukan. Wajib Pajak yang memahami peraturan dengan baik akan berupaya untuk meningkatkan kemauan untuk membarkan pajaknya.

H4: Kesadaran Membayar Pajak, Persepsi Atas Efektivitas Sistem Perpajakan dan Pemahaman Peraturan Pemerintah Nomor 23 Tahun 2018 berpengaruh positif terhadap Kemauan Membayar Pajak pada UMKM Sektor Perdagangan di Kabupaten Klaten.

Indikator yang digunakan untuk mengukur variabel persepsi atas efektivitas sistem perpjakan diadopsi dan dimodifikasi dari Widayati dan Nurlis (2010:9) yaitu; dokumen yang diperlukan dalam membayar pajak, informasi mengenai cara, tempat dan batas waktu pembayaran pajak, konsultasi sebelum melakukan pembayaran pajak, dan alokasi dana penghasilan.

\section{METODE PENELITIAN}

\section{Jenis Penelitian}

Menurut jenisnya penelitian ini merupakan penelitian kausal komparatif dengan pendekatan kuantitatif karena data yang disajikan berhubungan dengan angka. Penelitian ini bertujuan untuk menguji pengaruh Kesadaran Membayar Pajak, 


\section{JURNAL NOMINAL / VOLUME VIII NOMOR 2 / TAHUN 2019}

Persepsi Atas Efektivitas Sistem

Perpajakan dan Pemahaman Peraturan

Pemerintah Nomor 23 Tahun 2018

terhadap Kemauan Membayar Pajak pada

UMKM Sektor Perdagangan di Kabupaten Klaten.

\section{Tempat dan Waktu Penelitian}

Penelitian ini dilaksanakan di sektor perdagangan yang berada di Kabupaten Klaten yang dinaungi oleh Dinas Perindustrian Perdagangan dan Koperasi Kota Klaten. Penelitian dilakukan pada Bulan Februari-April 2019.

\section{Subjek Penelitian}

Populasi penelitian ini adalah UMKM sektor Perdagangan Kabupaten Klaten sebanyak 13.315. Teknik pengambilan sampel menggunakan purposive sampling dan didapatkan sampel sebanyak 388 .

\section{Prosedur}

Metode pengumpulan data yang digunakan adalah data primer yang berisi pertanyaan-pertanyaan yang ditunjukkan kepada responden.

\section{Data, Instrumen, dan Teknik}

\section{Pengumpulan Data}

Data yang digunakan dalam penelitian ini adalah data primer. Teknik yang digunakan untuk mengumpulkan data pada penelitian ini menggunakan kuesioner.

Instrumen penelitian yang digunakan dalam penelitian ini berupa angket tertutup, responden hanya memberikan checklist $(\sqrt{ })$ pada alternatif jawaban yang telah disediakan. Responden diminta melakukan penilaian berupa angka tentang pengaruh Kesadaran Membayar Pajak, Persepsi Atas Efektivitas Sistem Perpajakan dan Pemahaman Peraturan Pemerintah Nomor 23 Tahun 2018 terhadap Kemauan Membayar Pajak pada UMKM Sektor Perdagangan di Kabupaten Klaten.

\section{Teknik Analisis Data}

Uji validitas dan uji reliabilitas dalam penelitian ini dilakukan pada sampel berjumlah 30 responden dari total sampel penelitian yang digunakan. Sampel yang telah digunakan untuk uji coba instrumen tidak diikutsertakan kembali sebagai sampel penelitian. Uji validitas dengan menggunakan korelasi Pearson Product Moment dan uji reliabilitas menggunakan Cronbach Alpha. Sedangkan hipotesis penelitian diolah menggunakan alat analisis regresi linear sederhana untuk mengetahui pengaruh Kesadaran Membayar Pajak, Persepsi Atas Efektivitas Sistem Perpajakan dan Pemahaman Peraturan Pemerintah Nomor 23 Tahun 2018 secara parsial terhadap Kemauan Membayar Pajak pada UMKM Sektor Perdagangan di Kabupaten Klaten. Selain itu juga menggunakan regresi linear berganda untuk menguji secara bersama-sama pengaruh Kesadaran Membayar Pajak, Persepsi Atas Efektivitas Sistem Perpajakan dan Pemahaman Peraturan Pemerintah Nomor 23 Tahun 2018 terhadap Kemauan 
Membayar Pajak pada UMKM Sektor

Perdagangan di Kabupaten Klaten.

\section{HASIL PENELITIAN DAN}

\section{PEMBAHASAN}

\section{Hasil}

Hasil Uji Regresi Linear Sederhana untuk setiap hipotesis adalah:

Tabel 1. Hasil Regresi Linear Sederhana

\begin{tabular}{cccc} 
H1 & & & \\
\hline $\begin{array}{c}\text { Unstandarized } \\
\text { coefficient }\end{array}$ & T & Sig & Informasi \\
\hline 0,531 & 11,333 & 0,000 & $\begin{array}{c}\text { Hipotesis } \\
\text { Pertama } \\
\end{array}$ \\
& & & Diterima \\
\hline
\end{tabular}

Sumber : Data primer yang diolah, 2019

Berdasarkan tabel di atas, dapat dilihat

bahwa nilai thitung adalah sebesar 11,333 jika dibandingkan dengan tabel pada tingkat signifikansi 0,05, yaitu sebesar 1,966; maka $t_{\text {hitung lebih besar daripada } t_{\text {tabel }}}$ $(7,114>1,966)$. Nilai signifikansi sebesar 0,000 menunjukkan nilai yang lebih kecil dibandingkan dengan nilai pada tingkat signifikansi yang telah ditentukan sebelumnya, yaitu $0,05(0,000<0,05)$.

Tabel 3. Hasil Regresi Linear Sederhana H3

\begin{tabular}{cccc}
\hline $\begin{array}{c}\text { Unstandarized } \\
\text { coefficient }\end{array}$ & T & Sig & Informasi \\
\hline 0,550 & 9,881 & 0,000 & $\begin{array}{c}\text { Hipotesis } \\
\text { Ketiga } \\
\text { Diterima }\end{array}$ \\
\hline
\end{tabular}

Berdasarkan tabel di atas, dapat dilihat bahwa nilai thitung adalah sebesar 9,881 jika dibandingkan dengan $t_{\text {tabel }}$ pada tingkat signifikansi 0,05, yaitu sebesar 1,966; maka

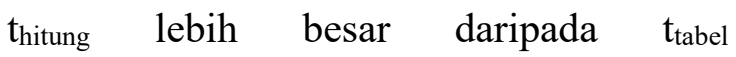
$(9,881>1,966)$. Nilai signifikansi sebesar 0,000 menunjukkan nilai yang lebih kecil $t_{\text {hitung lebih besar daripada }} t_{\text {tabel }}$ $(11,333>1,966)$. Nilai signifikansi sebesar 0,000 menunjukkan nilai yang lebih kecil dibandingkan dengan nilai pada tingkat signifikansi yang telah ditentukan sebelumnya, yaitu $0,05(0,000<0,05)$.

Tabel 2. Hasil Regresi Linear Sederhana $\mathrm{H} 2$

\begin{tabular}{cccc}
\hline $\begin{array}{c}\text { Unstandarized } \\
\text { coefficient }\end{array}$ & T & Sig & Informasi \\
\hline 0,345 & 7,114 & 0,000 & $\begin{array}{c}\text { Hipotesis } \\
\text { Kedua } \\
\end{array}$ \\
& & & Diterima \\
\hline
\end{tabular}

Sumber : Data primer yang diolah, 2019

Berdasarkan tabel di atas, dapat dilihat bahwa nilai thitung adalah sebesar 7,114 jika dibandingkan dengan $t_{\text {tabel }}$ pada tingkat signifikansi 0,05, yaitu sebesar 1,966; maka

dibandingkan dengan nilai pada tingkat signifikansi yang telah ditentukan sebelumnya, yaitu $0,05(0,000<0,05)$.

Tabel 4. Hasil Regresi Linear Sederhana $\mathrm{H} 4$

\begin{tabular}{ccc}
\hline $\mathbf{F}$ & Sig & Informasi \\
\hline 94,002 & 0,000 & $\begin{array}{c}\text { Hipotesis Keempat } \\
\text { Diterima }\end{array}$ \\
\hline
\end{tabular}

Sumber : Data primer yang diolah, 2019

Dari hasil pengujian diperoleh nilai $\mathrm{F}$ hitung sebesar 94,002 lebih besar dari $\mathrm{F}$ tabel sebesar 2,62 dengan signifikansi sebesar 0,000. Oleh karena nilai $F_{\text {hitung }}>F_{\text {tabel }}(94,002>2,62)$ dan signifikansi lebih kecil dari $0,05(0,000<0,05)$, maka dapat disimpulkan bahwa hipotesis keempat yang menyatakan "Kesadaran Membayar Pajak, Persepsi atas Efektivitas Sistem Perpajakan, dan Pemahaman 
Peraturan Pemerintah No. 23 Tahun 2018 berpengaruh positif terhadap Kemauan Membayar Pajak pada UMKM Sektor Perdagangan di Kabupaten Klaten" terbukti.

Selain itu, variabel Kesadaran Membayar Pajak merupakan faktor dominan yang mempengaruhi Kemauan Membayar Pajak pada UMKM Sektor Perdagangan di Kabupaten Klaten.

\section{Pembahasan}

Faktor pertama yang mempengaruhi Kemauan Membayar Pajak pada UMKM Sektor Perdagangan di Kabupaten Klaten adalah Kesadaran wajib pajak dapat diartikan sebagai itikad yang baik dari hati nurani seseorang untuk membayar pajaknya. Apabila UMKM Sektor Perdagangan di Kabupaten Klaten memiliki kesadaran untuk membayar pajak maka akan lebih meningkatkan kemauan membayar pajaknya. Kesadaran wajib pajak dalam kewajiban perpajakannya merupakan hal penting dalam penarikan pajak. Hal paling menentukan dalam keberhasilan pemungutan pajak adalah kemauan wajib pajak untuk melakukan kewajiban. Ketidakmaunya wajib pajak melakukan kewajiban tersebut adalah asas perpajakan, yaitu bahwa hasil pemungutan pajak tersebut tidak langsung dinikmati oleh para wajib pajak. Masyarakat tidak pernah tahu wujud kongkret imbalan dari uang yang dikeluarkan untuk membayar pajak
Faktor kedua yang mempengaruhi Kemauan Membayar Pajak pada UMKM Sektor Perdagangan di Kabupaten Klaten adalah Persepsi Atas Efektivitas Sistem Perpajakan. Persepsi atas efektivitas sistem perpajakan merupakan manfaat atau kesan yang dirasakan oleh wajib pajak terhadap sistem pembayaran pajak. Banyak ditemui bahwa sistem perpajakan ini sudah dimanfaatkan oleh beberapa pelaku usaha tetapi masih terdapat pemanfaatan sistem perpajakan masih menyulitkan untuk beberapa pelaku usaha. Karena pada Sistem perpajakan ini berbasis online jadi masih adanya responden yang mengalami kesulitan untuk mengakses pada sistem yang berbasis online.

Faktor ketiga yang mempengaruhi Kemauan Membayar Pajak pada UMKM Sektor Perdagangan di Kabupaten Klaten adalah Pemahaman Peraturan Pemerintah No. 23 Tahun 2018. Menurut Fidel dalam Fatmawati (2015), seorang individu akan kesulitan dalam mempelajari bidang perpajakan jika tidak mempunyai pemahaman mendasar terkait dengan pajak melalui konsep-konsep dasar perpajakan. Proses pemahaman konsep perpajakan tersebut dapat dilakukan melalui pengkajian terhadap aturan-aturan perpajakan yang berlaku.

Wajib Pajak yang kurang paham tentang peraturan perpajakan akan cenderung menjadi Wajib Pajak yang tidak 
taat. Semakin paham Wajib Pajak terhadap peraturan perpajakan yang berlaku, maka semakin paham pula Wajib Pajak terhadap sanksi yang akan diterima. Namun, apabila seorang Wajib Pajak paham tentang peraturan yang berlaku maka akan cenderung mau melaksanakan peraturan tersebut selama tidak bersifat merugikan. Peraturan Pemerintah Nomor 23 Tahun 2018 bertujuan untuk mempermudah pemahaman dan pelaksanaan Wajib Pajak dalam pemenuhan kewajiban perpajakan.

\section{SIMPULAN DAN SARAN}

\section{Simpulan}

Penelitian ini menunjukkan hipotesis diterima bahwa Kesadaran Membayar Pajak, Persepsi atas Efektivitas Sistem Perpajakan, dan Pemahaman Peraturan Pemerintah No. 23 Tahun 2018 berpengaruh positif terhadap Kemauan Membayar Pajak pada UMKM Sektor Perdagangan di Kabupaten Klaten, baik diuji secara parsial maupun simultan.

\section{Saran}

Peneliti selanjutnya agar dapat lebih mengembangkan penelitian ini dengan meneliti faktor lain yang dapat mempengaruhi Kemauan Membayar Pajak pada UMKM Sektor Perdagangan, misalnya: Pengetahuan, Kualitas Layanan, Pelayanan Fiskus, Sanksi Perpajakan, dan lain-lain. Sehingga akan semakin mendalam lagi jika ada faktor lain yang dapat memengaruhi Kemauan Membayar Pajak pada UMKM Sektor Perdagangan.

\section{DAFTAR PUSTAKA}

Ayu, Ida Dan Gayatri. (2017). "Pengaruh Pengetahuan Pemahaman Peraturan Pajak, Pelayanan Fiskus, Persepsi Efektivitas Sistem Perpajakan Terhadap Kemauan Membayar Pajak". Issn: 2302-8556 E-Jurnal Akuntansi Universitas Udayana Vol.19.2. Mei (2017): 1259-1289.

Dewan Perwakilan Rakyat Indonesia (2009) Undang-Undang Nomor 16 Tahun 2009 tentang Ketentuan Umum dan Tata Cara Perpajakan.

Fatmawati. (2015). Pengaruh Pemahaman Wajib Pajak Atas PP No.46 Tahun 2013 dan Implementasi Self Assessment System Terhadap Kepatuhan Wajib Pajak dengan Persepsi Wajib Pajak sebagai Variabel Moderasi (Studi Empiris Pada Pelaku UMKM Kerajinan Gerabah Kasongan). Skripsi. Universitas Negeri Yogyakarta.

Hardiningsih, Pancawati dan Yulianawati, Nila. (2011). Faktor-Faktor Yang Mempengaruhi Kemauan Membayar Pajak. Dinamika Keuangan dan Perbankan. Vol. 3, No. 1. Hal. 126 142.

Kementerian Pendidikan dan Kebudayaan Republik Indonesia. (2016). KBBI daring. Melalui website kbbi.kemdikbud.go.id. Diakses pada 3 Desember 2018

Kementerian Perindustrian. (2018). Perekonomian Indonesia. Diakses pada:http://www.kemenperin.go.id pada 6 Juli 2018.

Mahfud, Muhammad dan Syukriy, Abdullah. (2017). Pengaruh Pemahaman Peraturan Perpajakan, Kesadaran Membayar Pajak Dan 
Kualitas Pelayanan Perpajakan Terhadap Kepatuhan Wajib Pajak Badan (StudiEmpiris Pada Koperasi Di Kota Banda Aceh). Jurnal Magister Administrasi Pendidikan Pascasarjana Universitas Syiah Kuala. Vol.6 No.2 Tahun 2017.

Nugroho, Edwin. (2016). "Faktor-faktor Yang Mempengaruhi Kemauan Membayar Pajak Wajib Pajaj Orang Pribadi Yang Melakukan Pekerjaan Bebas Di Kpp Pratama Yogyakarta". Skripsi. Program Studi Akuntansi Fakultas Ekonomi Universitas Negri Yogyakarta.

Resmi, Siti. (2011). Perpajakan Teori dan Kasus. Edisi Keenam. Salemba Empat. Jakarta.

Sukarno, Puput Adi. (2019) Masih Minim Penerimaan Pajak dari Sektor UMKM. Diakses dari: https://ekonomi.bisnis.com pada 2 Januari 2019

Widayati dan Nurlis. (2010). "Faktorfaktor yang Mempengaruhi Kemauan untuk Membayar Pajak Wajib Pajak Orang Pribadi yang Melakukan Pekerjaan Bebas (Studi Kasus pada KPP Pratama Gambir Tiga)". Simposium Nasional Akuntansi XIII, Purwokerto 